\title{
THE SIEGE OF JAMMERBERGDRIFI: APRIL 6-25, 1900
}

Lt P.W. Wessels*

The siege of Jammerbergdrift can never be compared to any of the great battles of the Second War of Independence, but it was important because:

The British commander Gen Roberts had to delay his march to Pretoria for one month, and this waste of time enabled work on the forts (eg. Klapperkop) round Pretoria to be completed.

The siege and the subsequent relief as well as the delay of the British advance on Pretoria became a costly undertaking. Dr. W. van Everdingen wrote in "De Oorlog in Zuid-Afrika" that the importance lay in the operation that the British command had to undertake to keep the brave column out of the hands of the audacious Free Staters. Ten thousand troops from all corners of the country commanded by famous commanding officers were needed to drive off the investing Boers.

On April 2, 1900 a special meeting of the free State Volksraad was held in Kroonstad. There it was decided to change the war's tactics. President Steyn then issued the following statement: 'Under De Wet a new kind of war would begin. Oh, if only we could restart the war with the knowledge now available, what a different course the war would have taken.'

On March 31, Gen De Wet defeated the British forces at Sanna's Post, and on April 4, he captured a detachment of the Imperial Yeomany at Mostertshoek, near Reddersburg. From prisoners he learnt that Col. E.H. Dalgety was digging in with his troops at Jammerbergdrift, near Wepener. This force consisted of Colonials from the Cape Colony and to engage them in battle was a special challenge to the Free Staters, because in the words of De Wet: 'every burgher was fired by the desire to capture in particular the Cape Mounted Rifles and the Brabant's Horse. They were true Afrikaners and should not fight against us.' (C.R. De Wet: 'De strijd tusschen Boer en Brit).

These troops, mostly from the Eastern Province, were formed at the outbreak of the war into the Brabant Horse and were commanded by Brig. Gen Edward Yewd Brabant. The force had it's first skirmish at Stormberg, and after that established it's headquarters at Aliwal North. Lord Roberts ordered Brabant to occupy all the small towns in the Southern Free State. Capt Goddard, with 160 men, then took posession of Wepener on March $24,1900$.

This force's main task was to distribute Robert's socalled paperbombs which was the name given to his proclamation issued after the occupation of Bloemfontein, in which he promised a safe seturn to their farms to all burgers who would immediately lay down their arms and take the oath of neutrality. These burgers were also promised that they would not be taken prisoners of war nor would their property be confiscated.

Rumours that Gen J.H. Olivier was assembling a strong commando north of Ladybrand, caused the commander at Wepener to ask for reinforcements from Brabant at Aliwal North. From March 29, those reinforcements began arriving and Maj C. Maxwell of the Royal Engineers took over command.

On April 5, the total force at Wepener consisted of:

Officers Men

$\begin{array}{lrr}\text { Royal Engineers } & 1 & 10 \\ \text { Royal Scots } & 3 & 78 \\ \text { Cape Mounted Rifles } & 18 & 409 \\ \text { 1st Brabant Horse } & 25 & 320 \\ \text { 2nd Brabant Horse } & 29 & 430 \\ \text { Kaffrarian Rifles } & 23 & 370 \\ \text { Driscolls Scouts } & 3 & 53 \\ \text { Cape Mounted Rifles } & & \\ \text { Artillery } & 3 & 90 \\ \text { Royal Army Medical } & & \\ \quad \text { Corps } & 6 & 27\end{array}$

Just about the whole force was mounted.

The Artillery under the leadership of the later wellknown Henry T. Lukin (he was the commander of the S.A. Forces who gallantly defended Dellville Wood in France) consisted of 2 fifteen pounders, 2 naval guns of $12 \mathrm{lbs}$. each, 2 seven pounder field pieces and a 14 pounder Hotckiss. The Colonials could also rely on six Maxim Machine 
guns. On his arrival, Maxwell occupied Wepener and took up position about one mile north of the town. However, he wasn't satisfied with this position, and on April 3, decided on the site at Jammerbergdrift.

This hilly range along the river formed a basin of roughly seven miles in circumference, the width being about three miles. Although the koppies were surrounded by an outer ring of heights from where the inner ring of positions could be shelled, it was still an excellent defensive site. From the north west the attackers would have to approach in full view of the defenders. To the east, and the south, the Caledon river wasn't a usefull obstacle but the banks could be fully covered by small arms fire from the koppies.

The only weak spot in the defence was the western position where there was an open plain. The basin also provided excellent grazing for the horses; while the water supply from two vlei's and the river was adequate.

Maxwell carefully planned the occupation of the surrounding heights. On the rantjies to the left and right of the road, the Cape Mounted Rifles took up position. On the northern half circle of the hills the first and second Brabant Horse with three guns dug in with the Hotckiss rapid fire gun on the outer north-eastern corner. The eastern hills right opposite the old wagon bridge were defended by the Kaffrarian Rifles with one gun. The Royal Scots and Driscoll's Scouts were kept in reserve for quick dispatch to any threatened sectors. The main camp of the Colonials was on the site where the Ladybrand Co-operative shed now stand.

On April 5, Lt Col E.H. Dalgety took over the command from Maj Maxwell. Preparations continued and a temporary hospital was established in Struan House, home of the miller James Robertson. Stores and private homes in Wepener were stripped of all possible supplies and transported to the siege site.

Meanwhile Gen De Wet, on April 6, joined forces with the commando of Gen J.B. Wessels. That same evening, he reached a position to the right of the Colonials. Simultaneously Boer commandos from all directions converged on Jammerbergdrift so that eventually about 6,000 burgers were investing the position on April 9.

De Wet's opening attack came on the same day because of the burghers' hatred of the Colonials and also because he had little time left as he had received word that large British relieving forces were on their way from Bloemfontein, Reddersburg and Aliwal North.

During the night of April 8 and 9, the Boers crept through the bushes to the banks of the Caledon River from the direction of Wepener. From the south another group infiltrated into Sabella Spruit just west of the enemy. As usual the Colonials performed their ceremonies, and by $7 \mathrm{am}$. they were all back in their battle positions.

The signal for the Boer attack was a shell which landed in the British camp. The Colonials immediately struch their tents and rushed to their trenches. De Wet's bombardment started in earnest and it was kept up all day. From their hiding places the burghers kept up a heavy small arm fire on the Colonials. Everything that moved drew fire.

At the start, the heaviest Boer fire was from opposite the river, but De Wet fully realised that the western defences were the weakest. The ground there was rocky, with the result that the defenders could not dig in properly.

At the same time these defences were much lower than those of the Boers. De Wet therefore concentrated his attack on this front. The Cape Mounted Rifles who defended this section, were hardened men. Their commander, Maj Sprenger, was a brave man. Throughout the day he led his men unflinchingly while shell fragments and bullets whistled around him. Eventually, just when he sat down to rest, a bullet hit him in the heart.

At about 10 o'clock the Cape Mounted Rifles ran low on ammunition. As the ammunition dump was about 150 metres behind the front line, the troops had to run across open veld to replenish their supplies. Boer marksmen immediately cut loose and it was here that the Colonials suffered their heaviest losses. Toward the afternoon the Boer fire abated. Casualties on the first day of the siege was about 70 Colonial dead and wounded; the heaviest toll of the siege. That night the Colonials deepened their trenches, while they also reinforced their western defences with sand bags.

On April 9 and 10, the Boers received further reinforcement. These were men returning from the battle of Paardeberg who swelled the Boer ranks to 8,000 men. During the night of April 10 and 11, De Wet again launched an attack. 
Again the attack started on the western corner where the Cape Mounted Rifles were in position. Marksmen kept the outposts busy while the Boers tried to crawl up the koppie. Quick salvos from the trenches forced them back, but when the moon set at about 10 o'clock, the attack developed over the whole front. However, all efforts to break through were unsuccessful.

After this unsuccessful effort, De Wet then decided to surround the Colonials. Twice more he tried to persuade his forces to take the offensive. During the night of April 12, he positioned a battery to the west of the Colonial positions. this would enable him to be in a better position to shell the Cape Mounted Rifles, but the Boers were unwilling to launch another attack.

The bombardment and small arms fire for 16 days kept the besieged in their trenches. To make matters worse for the Colonials it started raining on April 12, and this continued for three days and nights. The trenches were mudlogged and the soldiers had to stand kneehigh in the mud. Rations would only be taken to the men under cover of darkness.

The intensity of the bombardment continued. The Boers on their side, did not forget their religious festivities. On Good Friday, April 13, a church service was held, and Easter was celebrated.

Col Dalgety's biggest problem now was the lack of ammunition. Every shell had to be counted. The following supply list indicate's not only how much ammunition was used, but also what was left when the siege was lifted.

Supplies at start

Per gun: 500

Per 15 pounder: 850

Per 12 pounder: 250

Per 7 pounder: 250

Per Hotchkiss: 350

(Sir F. Maurice: History of the War in South Africa)

Meanwhile, huge British troop movements were taking place in the southern Free State. From Bloemfontein the 11th Division, under Maj Gen Pole-Carew was on it's way to Jammerbergdritt. Lt Gen Leslie Runcle was leading the 8th Division from Edenburg, while Brabant himself was coming from Aliwal North.

Shortly after the start of the siege, Gen De Wet sent his brother Piet as well as Andries Cronje with a commando in the direction of Bloemfontein to delay the approaching British forces. Piet De Wet, with 1200 men and six guns tried to stop the advancing relief forces near Dewetsdorp, but superior numbers forced him back. Also to the south Gen Froneman was involved in a skermish with Brabant near Boesmanskop, but he also had to fall back.

Simultaneously with the advance of British reinforcements, 3,000 Basutos gathered on the Basutoland border, just above Wepener. According to Louis Creswicke ... "The Basutos, warlike and excited, were massing on the border, and a sword of Damocles, in the form of an exasperated legion of natives, threatened to drop on the Dutchmen's heads". These Basutos did everything in their power to encourage the Colonials and help the British forces.

Gen De Wet kept up the siege. He narrowed the circle round the Colonials, continually shifting his artillery and keeping up the bombardment of the enemy. From April 23, De Wet and his men could hear the thunder of British artillery from the direction of Dewetsdorp. News of the approaching danger from all directions was then received.

In Republican circles, as well as at Boer headquarters, De Wet's position caused great concern. Pres Kruger warned Pres Steyn (in Kroonstad) of the great danger of De Wet's position. Gen Louis Botha hastened to Dewetsdorp and from there visited De Wet's camp at Hoffmansrust. $\mathrm{He}$ ordered the immediate withdrawal of all Boer forces.

On April 25, De Wet lifted the siege and his commando moved in the direction of Thaba'Nchu. When the British generals reached Jammerbergdrift on April 27, De Wet had escaped.

De Wet himself calls the siege of Jammerbergdrift a hopeless failure. During the siege of 16 days the Colonials lost three officers and 25 men, while 11 officers and 130 men were wounded.

The Colonials were buried in the Robertson family cemetery, next to the tarred road. Boer casualties were five dead and 13 wounded.

In the history of the Second War of Independence the defence by the Colonials of Jammerbergdrift was of the highest order. Their courage earned them the admiration of friend and foe. 


\section{Bibllography}

1. Professor J.J. Oberholster: Wepener 1869-1969.

2. J.H. Breytenbach: Gedenkalbum van die Tweede Vryheidsoorlog

3. Dr. W. van Everdingen: De Oorlog in Zuid-Afrika 1.
4. L.P. Penning: De Oorlog in Zuid-Afrika.

5. C.R. de Wet: De Strijd tusschen Boer en Brit.

6. Sir F Maurice: History of the War in S.A. II.

7. L.S. Emery: The Times History of the War in South Africa IV.

Map showing the dispositions of the various forces during the siege

DIRECTIONS

British

Boers

Guns

Trenches

As che guns on borth sides

mere shilitod obout during

strom are only temporary

Eare noc meont co indicale

die ocluol numper of guns

These were

Brilish/3/Tguns 6 6maxims)

Boer: Tguns 4 some pampoms

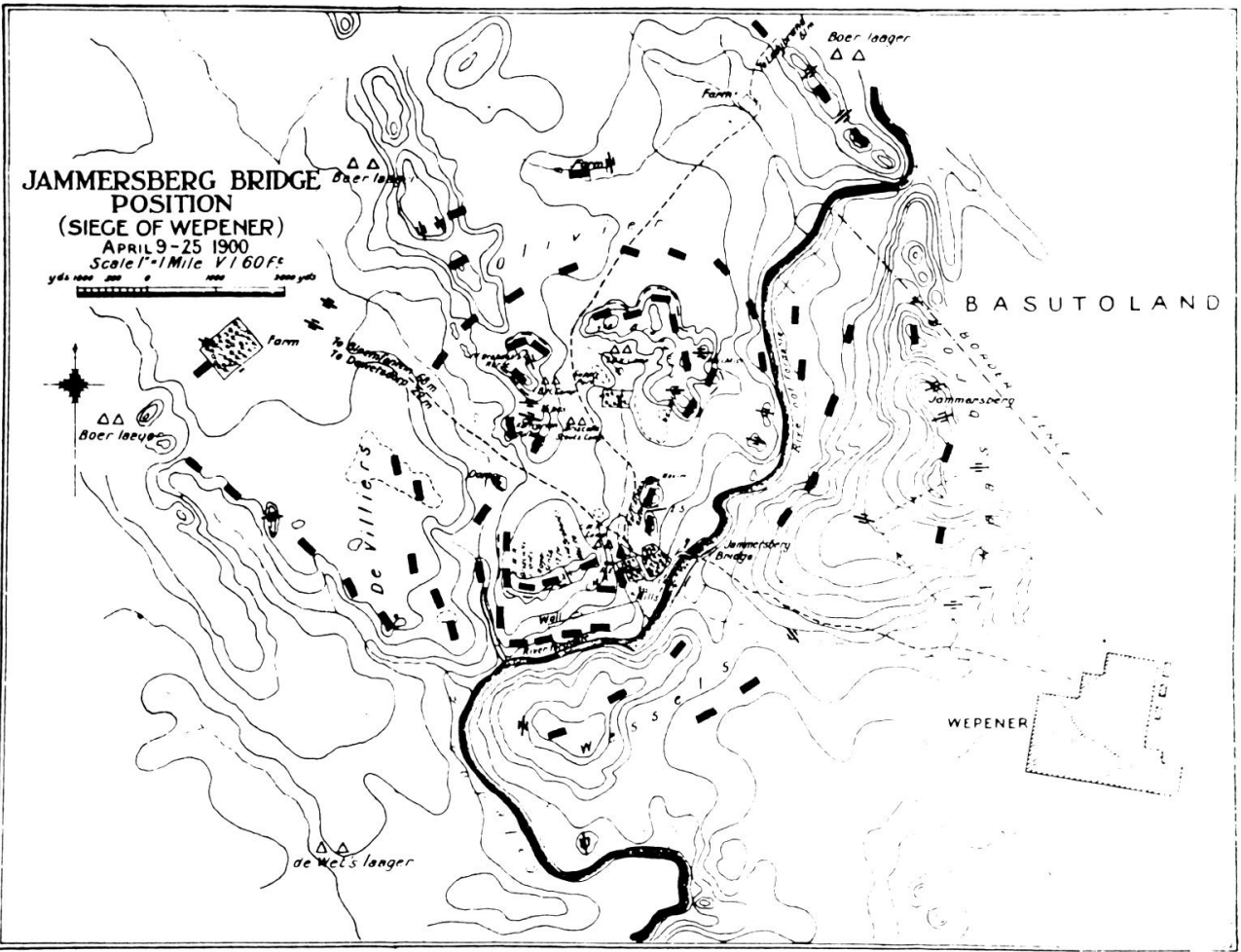

Jammersberg Bridge position

Slege of Wepener: Aprll 9-25 1900

(841002015)

The old historic battlefield is now being restored by the Rapportryerskorps of Wepener with the assistance of the War Museum in Bloemfontein.

Phase One envisages the exhibition of relics and the history of the siege in the Wepener Library. Phase Two will include the construction of a look-out post over the battlefield with the positions of the various units indicated on the field. 